\title{
The renin-angiotensin-aldosterone system and the cardiac natriuretic peptides
}

\author{
A Mark Richards
}

Natriuretic peptides and the reninangiotensin-aldosterone system (RAAS) have reciprocal effects at multiple sites and in varied situations. They interact in health and cardiovascular disease to influence renal, endocrine, and haemodynamic function and cardiovascular cell growth. The atrial natriuretic peptide (atrial natriuretic factor, ANF) discovered by De Bold in $1981^{1}$ was cloned and sequenced by molecular biological techniques in $1984 .^{2}$ The related peptides, brain natriuretic peptide (BNP) and C-type natriuretic peptide (CNP), were sequenced in 1988 and 1990, respectively. ${ }^{34}$ The mature forms of the peptides share a common core structure consisting of a 17-amino acid ring with some conservation of amino acid residues between peptides (fig 1). ${ }^{24} \mathrm{ANF}$ is present at high concentrations in atrial tissue, and in lesser amounts in the central nervous system and plasma. BNP was originally identified in the porcine brain, but subsequent work showed that it is primarily a cardiac hormone. CNP, the most recently discovered member of the natriuretic peptide family, has no carboxy terminal extension (fig 1). It is widespread in vascular endothelium and is the most prevalent of the three peptides within the central nervous system, while little is present in the heart.

The natriuretic peptides exert their biological activity through specific cell receptors. Three natriuretic peptide receptors (NPR) have been characterised. NPR-A and NPR-B have guanylate cyclase activity and mediate biological activity through the second messenger cyclic guanosine monophosphate (cGMP). NPR-C is not guanylate cyclase linked, and functions as a "clearance receptor", removing natriuretic peptides from the circulation. ${ }^{5}$ ANF and BNP stimulate cGMP production through the NPR-A receptor. The NPR-B receptor is selective for CNP. ${ }^{6}$ The NPR-C (clearance receptor) binds all three of the natriuretic peptides. Natriuretic peptides are also subject to clearance by enzymatic degradation. The neutral endopeptidase EC $3 \cdot 4 \cdot 24 \cdot 11$ contributes to ANF clearance (and to a lesser extent BNP clearance) in humans. ${ }^{7}$ The biochemistry of natriuretic peptides is further detailed in a recent review. ${ }^{8}$

The focus of the present review is the interaction of the cardiac natriuretic peptides with the RAAS. Studies in humans will be reviewed, with additional information from in vitro or intact animal experiments where appropriate.

\section{Reciprocal responses of natriuretic peptides and RAAS}

Secretion of ANF from the atria and BNP from cardiac ventricles is regulated by atrial distension and intraventricular pressures, respectively. The RAAS is activated with contraction of plasma volume and fall in renal perfusion. Renin secretion is stimulated through effects on the afferent arterial baroreceptor system, shifts in the filtered load of sodium presented to the macula densa, and by changes in renal sympathetic traffic. Renin stimulates production of circulating angiotensin II, a major secretagogue for aldosterone. The natriuretic peptides enhance natriuresis, lower blood pressure, and promote

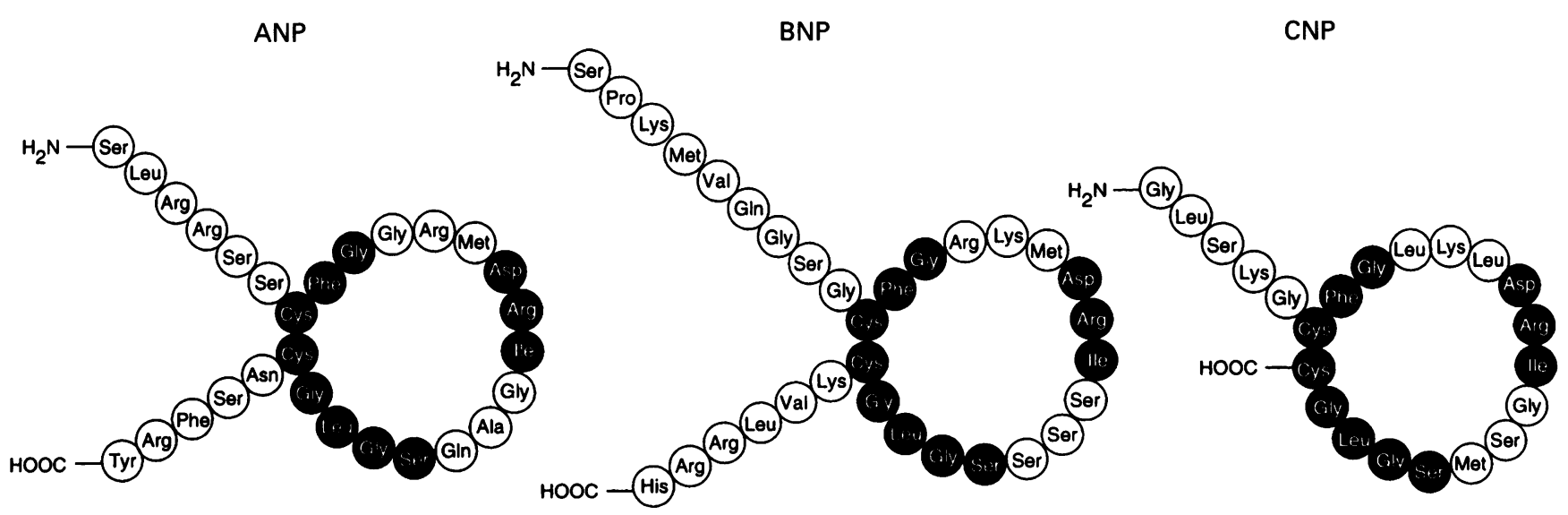

Figure 1 Mature forms of peptides belonging to the human atrial natriuretic peptide ( $A N P$ ), brain natriuretic peptide (BNP), and $C$-type natriuretic peptide (CNP) families. Filled circles are amino acids common to all three peptides. The mature forms shown are ANF, BNP-32, and CNP-22. Reproduced with permission from Yandle et al. ${ }^{8}$ 
a contraction of plasma volume by shifting fluid volume from the intravascular to the extravascular space. ${ }^{9}$ In contrast, the RAAS promotes maintenance of circulating volume and arterial pressure through both renal sodium reabsorption and vasoconstrictor effects.

In view of these differing stimuli for secretion and opposed end organ biological effects, it is not surprising that plasma natriuretic peptide concentrations and circulating RAAS activity alter in reciprocal fashion in the face of a variety of physiological and experimental stimuli. For example, intravenous saline challenge increases plasma concentrations of ANF (although not BNP) while suppressing the RAAS. ${ }^{10}$ Similarly, administration of diuretics, or conversely, expansion of central blood volume by means of lower body immersion, produces clear reciprocal changes in natriuretic peptide and RAAS activity. ${ }^{11}$ Dietary changes leading to shifts in cumulative sodium balance induce a direct parallel shift in plasma natriuretic peptides but a reciprocal change in renin. ${ }^{10}$ These observations do not allow distinction between the possibilities of independent reciprocal responses of natriuretic peptides and the RAAS to a given stimulus and potential direct effects of one circulating factor on the other.

\section{Natriuretic peptide infusions in normal man}

Administration of high doses of ANF, with associated substantial falls in arterial pressure, has no effect on plasma renin activity..$^{1213}$ During an early experiment in which high doses of ANF caused a pronounced fall in blood pressure, plasma renin activity increased while aldosterone secretion was suppressed..$^{13}$ Therefore, in addition to any effect of ANF on aldosterone through the renin-angiotensin system, there is also a direct inhibitory effect of natriuretic peptides on the adrenal zona glomerulosa. Physiological doses of ANF consistently suppress both plasma renin activity and aldosterone concentrations. ${ }^{91415}$ Low dose ANF infusions inducing small increments in plasma ANF confined to the mid-portion of the normal resting range briskly suppressed plasma renin activity and aldosterone concentrations by one third to one half below matched placebo values (fig 2) ${ }^{14}$ ANF inhibits the renin response in man to head up tilt, loop diuretic, isoprenaline, prostaglandin, and angiotensin converting enzyme (ACE) inhibition. ${ }^{15}$ Age, arterial blood pressure, sodium status, and posture all affect responses to natriuretic peptides, and conflicting reports are largely due to inadequate control of these potentially confounding variables. ${ }^{16}$ Overall, in the absence of major haemodynamic disturbance with its consequent neurosympathetic activation, secretion of both renin and aldosterone is readily inhibited by small changes in plasma ANF.

BNP has comparable ability to suppress the RAAS. In normal volunteers, low dose BNP $(2 \mathrm{pmol} / \mathrm{kg} / \mathrm{min}$ over $3 \mathrm{~h}$ ) induced an increase

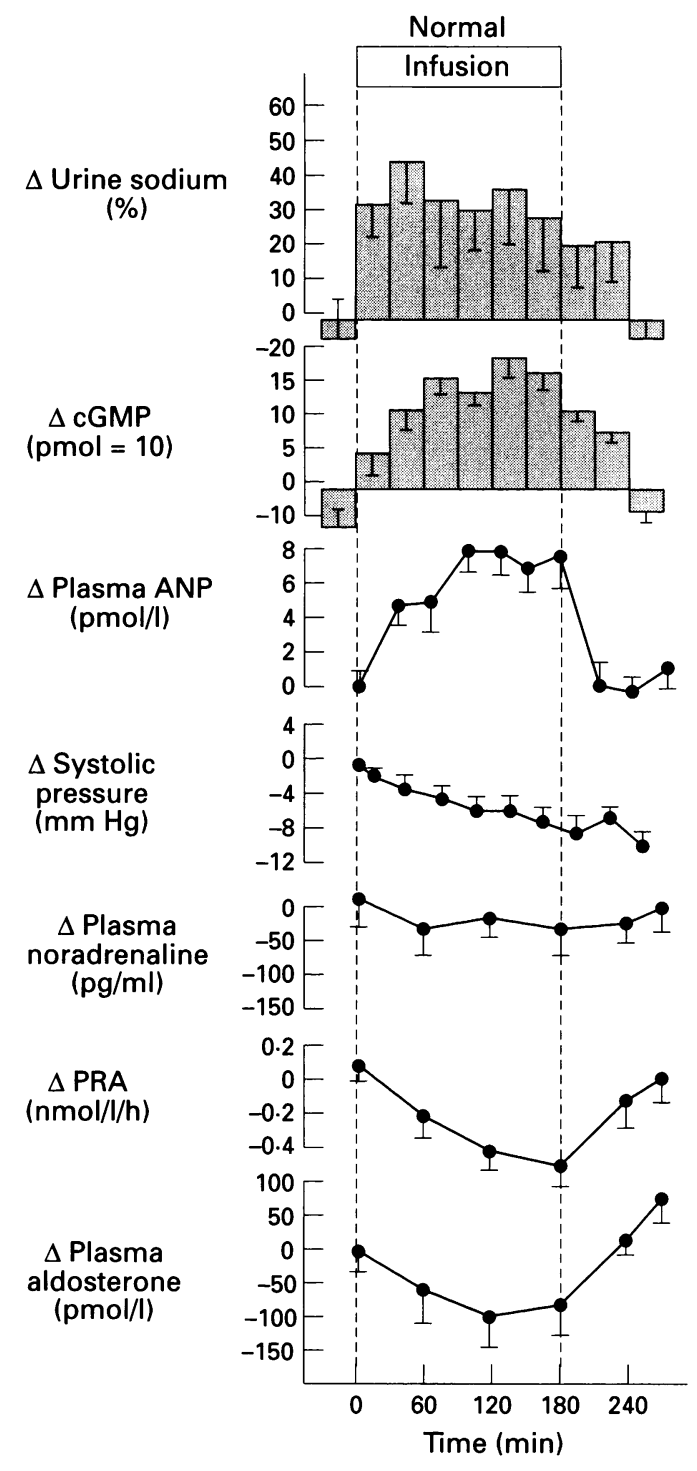

Figure 2 Response to intravenous infusions of human atrial natriuretic factor $(A N P)(0.75 \mathrm{pmol} / \mathrm{kg} / \mathrm{min}$ for 180 min) in six normal subjects equilibrated on a daily sodium intake of $150 \mathrm{mmol}$. Values (mean with SEM) are plotted as change $(\Delta)$ from time matched levels on the control day for urinary excretion of sodium and cyclic guanosine monophosphate (cGMP), plasma ANP, systolic pressure, plasma noradrenaline, plasma renin activity (PRA) and plasma aldosterone (bottom panel). Reproduced with permission from Espiner et al. ${ }^{81}$

in plasma BNP to levels similar to those observed in mild heart failure. Natriuresis occurred, together with rapid suppression of renin activity and aldosterone concentrations to $50 \%$ of placebo values. ${ }^{17}$ Little information is available comparing the effects of ANF and BNP on the renin-angiotensin-aldosterone system. Cargill et al ${ }^{18}$ studied normal volunteers in a three way crossover study with administration of $10 \mathrm{pmol} / \mathrm{kg} / \mathrm{min}$ of ANF, $\mathrm{BNP}$, or vehicle, with concomitant infusion of angiotensin II $(6 \mathrm{ng} / \mathrm{kg} / \mathrm{min})$. ANF and BNP had similar vasodilator effects. However, ANF was twice as potent as BNP in suppressing the aldosterone response to angiotensin II. We have confirmed this finding in a similar experiment incorporating stepped infusions of angiotensin II on a background of lower dose (2 $\mathrm{pmol} / \mathrm{kg} / \mathrm{min}$ ) infusions of ANF and BNP (Hunt PJ et al, unpublished data). 
CNP infused in normal men ${ }^{19}$ at a dose of 5 $\mathrm{pmol} / \mathrm{kg} / \mathrm{min}$ over a period of $2 \mathrm{~h}$ in placebo controlled studies increased plasma immunoreactive CNP levels to $60 \mathrm{pmol} / 1$. Plasma ANF rose (approximately $2 \mathrm{pmol} / \mathrm{l}$ ), as did plasma cGMP (approximately $1 \mathrm{nmol} / \mathrm{l}$ ). Aldosterone concentrations fell, whereas plasma angiotensin II levels were not altered. CNP had no significant effect on the aldosterone or pressor responses to angiotensin II infusions. The observed effects on aldosterone and plasma cGMP may have been due to competitive displacement by CNP of ANF in common degradative pathways. In view of the likely role of CNP as a paracrine rather than endocrine hormone, the physiological or pathophysiological significance of these findings is uncertain.

The mechanisms underlying natriuretic peptide inhibition of renin secretion are not fully defined. ${ }^{15}$ Peptide-induced dilatation of the afferent glomerular arteriole may stimulate baroreceptors involved in the control of renin release from the juxtaglomerular apparatus. Enhanced delivery of sodium to the macula densa induced by natriuretic peptides will also inhibit renin release. The possibility that natriuretic peptides also act directly on juxtaglomerular cells to inhibit renin release has been addressed by in vitro experiments, but the data are conflicting.

\section{Natriuretic peptides and angiotensin II bioactivity}

Natriuretic peptides oppose most of the known biological effects of angiotensin II. They antagonise angiotensin II induced aldosterone production. ${ }^{1820}$ Natriuretic peptide induced natriuresis is partly due to antagonism of the effects of angiotensin II on glomerular permeability and proximal tubular sodium reabsorption, as well as aldosterone secretion into the distal nephron. ${ }^{152122}$ Recently, Garcia and Garvin ${ }^{23}$ have published evidence suggesting that the two peptides interact in the proximal straight tubule of the nephron through a mechanism requiring phosphorylation mediated by cGMP dependent protein kinase. In normal man, McMurray and Struthers have shown that ANF inhibits angiotensin II induced antinatriuresis, and that angiotensin II inhibits ANF induced natriuresis at doses which do not disturb systemic haemodynamics. $^{24}$

Sodium depletion enhances the aldosterone response to angiotensin II. ${ }^{25}$ Some data suggest that concomitant shifts in natriuretic peptides may contribute to the sodium related changes in the dose-response relation between angiotensin II and aldosterone secretion. In sodium depleted dogs receiving a background infusion of ANF calculated to cause restitution of plasma ANF concentrations to salt replete values, the enhanced aldosterone response to angiotensin II was significantly attenuated..$^{26}$ However, data in humans from Tuchelt et $a l^{27}$ and Clinkingbeard et $a l^{28}$ are inconclusive.

Natriuretic peptides alter blood pressure through a range of mechanisms which include contraction of plasma volume, inhibition of renin and aldosterone secretion, and a direct vasodilator effect. Interaction between natriuretic peptides and the RAAS may also occur in some blood vessels. In isolated vascular preparations, ANF shows a pronounced antagonism of angiotensin II induced vasoconstriction in large conduit arteries such as preparations of isolated aorta. ${ }^{29}$ In contrast, peripheral vessels (cerebral and mesenteric vessels in the rat and glomerular arterioles in the rabbit) preconstricted with noradrenaline or angiotensin II are insensitive to ANFs. Early human studies do not suggest preferential antagonism by natriuretic peptides of the net pressor effects of angiotensin II over that of noradrenaline. ANF and angiotensin II both constrict renal efferent arterioles, ${ }^{30}$ suggesting a common mechanism whereby both peptides preserve intraglomerular pressure and filtration.

Natriuretic peptides and angiotensin II may exert counterbalancing effects upon vascular cell growth and hypertrophy. Angiotensin II is a promoter of vascular smooth muscle cell growth. ${ }^{31}$ ANF inhibits vascular smooth muscle cell proliferation ${ }^{32}$ and attenuates the action of angiotensin II on vascular hypertrophy ${ }^{33}$ independently of its induction of proto-oncogenes. Natriuretic peptides antagonise growth factor dependent DNA synthesis and cell proliferation of cardiac fibroblasts. ${ }^{34}$ These counterpoised effects of natriuretic peptides and angiotensin II on cardiovascular cell growth suggest that the combination of ACE inhibition with natriuretic peptide enhancement (for example, with neutral endopeptidase inhibition) may oppose vascular and cardiac hypertrophy in human cardiovascular disease.

Angiotensin II and natriuretic peptide interactions may influence cardiac conduction and rhythm. Angiotensin II has a direct toxic effect upon cardiac cells, ${ }^{35}$ and in the setting of cardiac ischaemia angiotensin II may be proarrhythmic. Little is known of the effect of natriuretic peptide on cardiac conduction and rhythm. Crozier et $a l^{36}$ infused exogenous ANF during cardiac electrophysiological studies in man. ANF induced falls in intraatrial conduction time, $\mathrm{PR}$ interval, right atrial effective refractory period, and ventriculoatrial refractory period. In the isolated perfused heart (rat), angiotensin II exacerbated ischaemia induced ventricular fibrillation, impaired cardiodynamics, and increased the release of creatine kinase. These effects were abolished by ANF, ${ }^{37}$ which increased myocardial glycogen, ATP, and creatine phosphate, and decreased lactate levels. Angiotensin II induced deterioration in these metabolic variables. Hence, natriuretic peptides may offer protection against the metabolic and arrhythmic consequences of cardiac ischaemia and reperfusion. Functional antagonism of angiotensin II may underlie this beneficial effect.

Natriuretic peptides and angiotensin II in the central nervous system

Angiotensin II given into the cerebral ventri- 
cles raises blood pressure, stimulates drinking, salt preference and adrenocorticotropic hormone release, and inhibits renal renin release. These central nervous system actions of angiotensin II are similar to those observed with peripheral administration. In contrast, central nervous system angiotensin II induces natriuresis while peripheral angiotensin II promotes sodium retention. Intracerebroventricular ANF antagonises all of the central nervous system effects of angiotensin II. ${ }^{15}$

The brain renin-angiotensin system may influence ANF secretion. Itoh et al ${ }^{38}$ showed that intracerebroventricular angiotensin II did not alter basal plasma ANF, but the natriuretic peptide response to systemic volume loading was enhanced. However, the angiotensin II AT-1 receptor blocker losartan given intracerebroventricularly in normal sheep and sheep with heart failure raised peripheral renin, angiotensin II, and aldosterone concentrations in both states without significant effects on plasma natriuretic peptides (Rademaker MT, et al unpublished data).

There is little information about BNP or CNP given into the cerebral ventricles. In conscious sheep, intracerebroventricular ANF produced little change in basal hormones and haemodynamics, whereas CNP induced a prompt fall in mean arterial pressure with an abrupt early increase in both plasma cortisol and aldosterone, followed by a decline to values equal to or below control levels. ${ }^{39}$ The data indicate that central nervous system CNP reduces arterial pressure (without a reflex tachycardia) and suppresses the adrenocortical response (fig 3).

Systemic angiotensin II enhances natriuretic peptide secretion by haemodynamic and direct mechanisms. Pressor doses of angiotensin II increased ANF secretion in the rat proportionally to concomitant changes in right atrial pressure. ${ }^{40}$ In humans, Schenker et $a l^{41}$ showed that vasopressor infusions of angiotensin II also enhanced plasma ANF levels. Volpe et $a l^{42}$ found that subpressor doses of angiotensin II administered to dogs during saline loading (with and without converting enzyme inhibition) significantly increased plasma ANF levels without change in atrial pressure. In isolated atrial appendages and in crude rat atrial tissue preparations, angiotensin II stimulates ANF release consistent with a direct effect of angiotensin II independent of haemodynamic changes. ${ }^{15}$

\section{ACE and natriuretic peptides}

Early in vitro studies suggesting that converting enzyme inhibition slowed the metabolism of ANF have not been reproduced. ${ }^{43}$ In man, conflicting reports appeared as to whether ACE inhibition raised or lowered endogenous plasma ANF. ${ }^{15}$ Reduced ANF induced natriuresis during ACE inhibition has been a consistent finding. This effect may simply reflect falls in renal perfusion pressures reducing the renal response to ANF. Richards et al studied supine, salt loaded, normal volunteers. In this setting, ACE inhibition caused little change in blood pressure and did not alter metabolic clearance or bioactivity of infused exogenous ANF. ${ }^{44}$

A sole report from Kawaguchi et $a l^{45}$ indicated that ANF was able to inhibit ACE activity in a dose dependent manner in cultured pulmonary endothelial cells.

\section{Inhibition of natriuretic peptide metabolism}

Blockade of natriuretic peptide metabolism provides further information on the action of natriuretic peptides on the RAAS. Maack et $a l^{5}$ discovered non-guanylyl-cyclase-linked "clearance" receptors by using an ANF ana-
Figure 3 Schemative diagram showing the regulation and actions of natriuretic peptides. Reproduced with permission from Espiner et al. $^{82}$

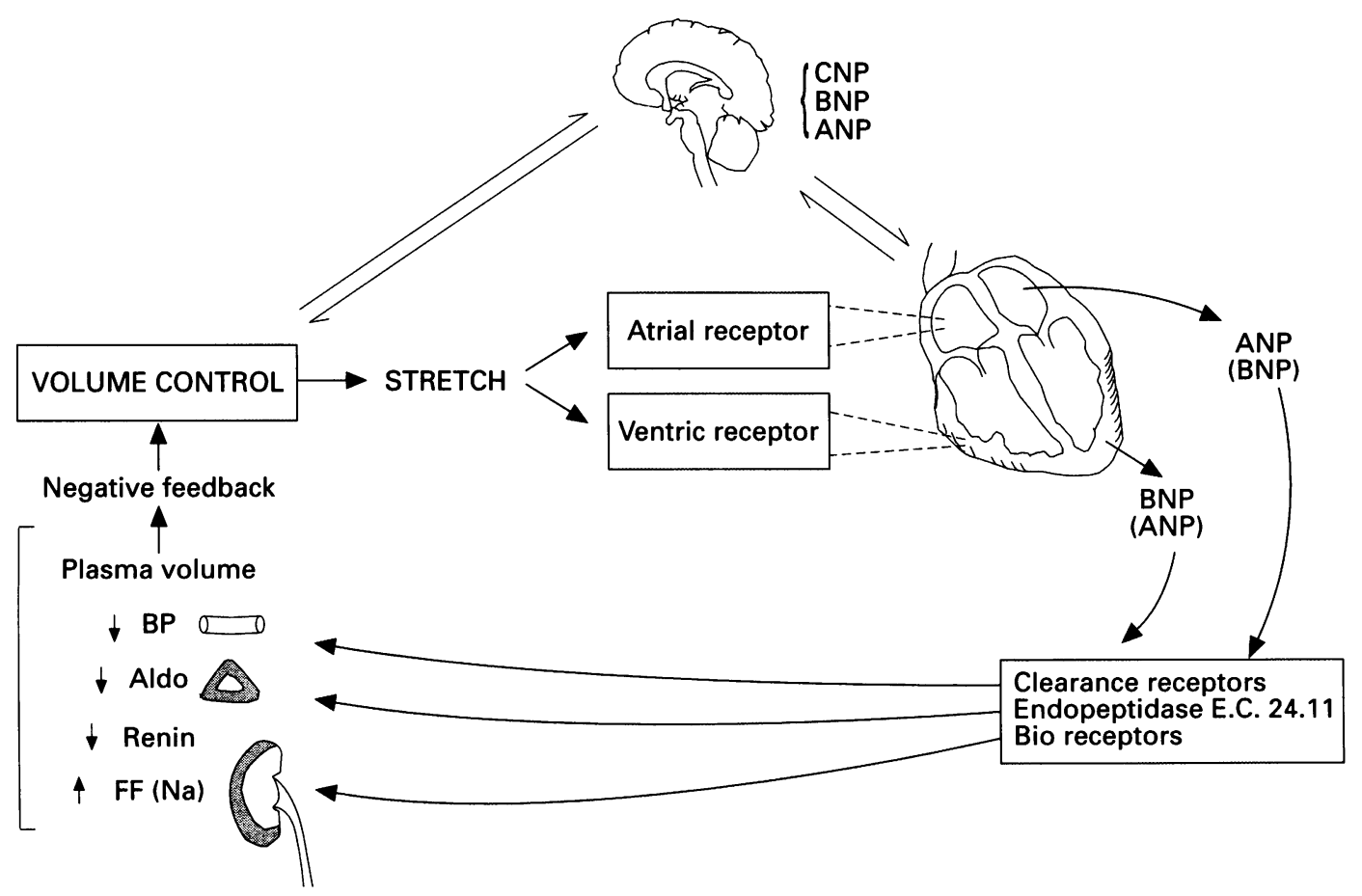


logue, ANPC 4-23, which had no direct activity in vitro but which elicited a natriuresis when given to intact rats. The modified ligand displaced biologically active natriuretic peptide from $\mathrm{C}$ receptors. While many reports confirm the diuretic and vasodepressor effects of giving a variety of NPR-C ligands, few describe the concomitant effects on the RAAS. Wegner et $a l^{46}$ found a minor suppression of renin below time matched placebo values with administration of the clearance receptor ligand AP811 in anaesthetised dogs. No data are available concerning the effects of such ligands on RAAS activity in humans.

The neutral endopeptidase EC $3 \cdot 4 \cdot 24 \cdot 11$ is pivotal in the initial enzymatic degradation of $\mathrm{ANF}^{7}$ and also contributes to clearance of BNP. In man and in animals, administration of neutral endopeptidase inhibitors results in modest rises in plasma ANF together with a transient natriuresis above time matched placebo values. ${ }^{4748}$ Single doses of neutral endopeptidase inhibitors initially suppress levels of plasma renin and aldosterone in association with the initial stimulus to plasma natriuretic peptide concentrations, ${ }^{47}$ but with sustained dosing in normal volunteers activation of the RAAS occurs. ${ }^{49}$ Presumably decreased blood pressure and negative sodium balance override the primary inhibitory effect of enhanced tissue natriuretic peptide on renin secretion. In addition, in man, neutral endopeptidase inhibition interferes with clearance of angiotensin II..$^{50}$

\section{Natriuretic peptide blockade}

Clarification of the role of natriuretic peptides with respect to the RAAS has been handicapped by the absence of a specific, potent, and safe antagonist to natriuretic peptides suitable for administration to humans. Such an agent would offer important complementary evidence to that presented above. Several studies have already shown that physiological increments in plasma or tissue natriuretic peptides significantly inhibit the RAAS.9 ${ }^{9151718}$ If it could also be shown that a specific blockade of endogenous natriuretic peptide produced the opposite effect, that is, activation of the RAAS, then the evidence that endogenous natriuretic peptides play a "tonic" role in regulation of RAAS activity would be compelling. Although such data are not available from human experiments, their near equivalent can be gleaned from animal data documenting the effect of monoclonal antibodies to ANF, and also from the use of the polysaccharide natriuretic peptide antagonist HS142-1 which selectively inhibits the binding of ANF and BNP to guanylyl cyclase linked natriuretic peptide receptors. ${ }^{51}$

Stasch and colleagues have reported that the expected suppression of plasma renin activity and plasma aldosterone concentrations by acute hypervolaemia is abolished by pretreatment with monoclonal antibody directed against ANF. ${ }^{52}$ Rudd $^{53}$ and colleagues, employing this monoclonal antibody in rats, showed falls in basal natriuresis and a $50 \%$ rise in plasma aldosterone. In rats, HS142 abolished the natriuretic response to ANF and BNP ${ }^{54}$ Similar effects were observed in anaesthetised dogs, in which HS142 decreased basal sodium excretion in association with a doubling of plasma renin activity. Together, these data indicate an important role for endogenous natriuretic peptides in regulating basal and stimulated plasma renin activity and aldosterone concentrations.

\section{Hypertension}

Plasma natriuretic peptide concentrations rise progressively with increasing severity of hypertension, ${ }^{55}$ and plasma ANF and BNP are correlated with left ventricular mass. Plasma ANF and the RAAS may both be disturbed in hypertensive disorders. In Gordon's syndrome $^{55}$ (hypertension, hyperkalaemia, volume expansion, and low renin), plasma ANF is low and has a subnormal response to saline challenge. Deficient ANF responses may be attenuated in Gordon's syndrome and may therefore contribute to volume expansion and hypertension in this state.

Luparini et $a l^{56}$ investigated the effect of changes in sodium status on the ANF response to angiotensin II infusions in patients with "non-modulating" 57 essential hypertension with blunted renal and RAAS responses to shifts in sodium status. In contrast to modulators, non-modulators show no increase in plasma ANF in response to infusions of angiotensin II at either low or high sodium intakes. In patients with essential hypertension (divided into "renin responsive" and "renin unresponsive" subgroups on the basis of their plasma renin response to challenge with frusemide and upright posture), renin unresponsive patients showed an enhanced plasma ANF response to hypertonic saline challenge. ${ }^{58}$ Natriuretic peptide levels may be an important codeterminant of the RAAS response to change in sodium status and of natriuretic responses to sodium challenge.

In primary aldosteronism, plasma ANF is appropriately raised and falls with excision of the adrenal adenoma or during treatment with aldosterone antagonists. ${ }^{55}$ Renovascular hypertension and hypertension associated with chronic renal impairment are also associated with increased plasma natriuretic peptide concentrations.

\section{CNP}

Plasma concentrations of CNP are far lower than concomitant levels of ANF or BNP. This is consistent with the putative paracrine role for this peptide. Plasma CNP concentrations are not altered in human hypertension and the values do not correlate with concurrent levels of BNP. ${ }^{59}$ Sited in vascular and central nervous system tissues, CNP has the potential to influence arterial pressure and RAAS activity. Central nervous system CNP lowered blood pressure and adrenocortical secretion in normotensive sheep. ${ }^{39} \mathrm{CNP}$ inhibits growth of rat vascular smooth muscle cells. It also inhibits 
arterial intimal thickening after vascular injury in rat carotid arteries. ${ }^{60}$ These vascular antitrophic actions are the opposite of those expected for angiotensin II, suggesting a possible functional antagonism between CNP and angiotensin II with respect to cardiovascular cell growth.

\section{Natriuretic peptide infusions in human hypertension}

Early studies confirmed the natriuretic and hypotensive effects of ANF in human hypertension, but the large doses of ANF used in these studies induced compensatory reflex responses that tended to disguise the primary inhibitory effect of ANF on the RAAS which became apparent in later work. In essential hypertension, ANF doses of 1 and 2 $\mathrm{pmol} / \mathrm{kg} / \mathrm{min}$ increased plasma ANF to concentrations which remained within the range observed in hypertension. Despite a clear, dose related fall in arterial pressure and a significant natriuresis, RAAS activity was not stimulated. ${ }^{61}$ ANF infusions $(0.75 \mathrm{pmol} / \mathrm{kg} /$ min) inducing a shift in plasma peptide concentrations, entirely within the normal resting range, produced a natriuresis together with consistent suppression of plasma renin activity and aldosterone to less than $50 \%$ of time matched placebo values. ${ }^{62}$

Recently Ferri et $a l^{63}$ have compared the effects of ANF infused into low renin and normal renin essential hypertensives. Basal plasma ANF was higher in low renin than in normal renin hypertensives. ANF $(0.7 \mathrm{pmol}$ $\mathrm{kg} / \mathrm{min}$ for $3 \mathrm{~h}$ ) induced a more rapid and pronounced decrement in the plasma aldosterone of low renin patients.

With respect to secondary hypertension, there are at least four reports of ANF given in primary aldosteronism ${ }^{55}$ at doses ranging 1.6 to $32 \mathrm{pmol} / \mathrm{kg} / \mathrm{min}$. Blood pressure lowering and natriuretic effects were substantial and similar to those observed in essential hypertension. Unsurprisingly, plasma aldosterone levels were not altered by ANF. Hirata et al ${ }^{64}$ infused ANF ( $8 \mathrm{pmol} / \mathrm{kg} / \mathrm{min}$ for $40 \mathrm{~min}$ ) into renal parenchymal hypertensive, renovascular hypertensive, and normotensive control subjects. Blood pressure $(-5 \%)$ and plasma aldosterone $(-40 \%)$ decreased by a similar proportion in the three groups. Interestingly, plasma renin activity was not significantly affected in any group.

Overall, the inhibitory effects of natriuretic peptides on the RAAS are observed in both primary and secondary human hypertension, but may be modified by baseline RAAS activity.

Human BNP (2 pmol $/ \mathrm{kg} / \mathrm{min})$ infused intravenously in controlled studies of untreated patients with essential hypertension increased plasma BNP to values (20-30 $\mathrm{pmol} / \mathrm{l}$ ) similar to those previously observed in other patients suffering from mild heart failure. Plasma aldosterone was significantly suppressed to $50 \%$ of placebo values, in association with the $2 \cdot 5$-fold increase in sodium excretion. ${ }^{65}$ Plasma renin activity was also inhibited. A later, similar study from
Lazzeri et $a l^{66}$ induced a comparable increase in plasma BNP concentrations in association with a similar increase in sodium excretion and a trend towards suppression of plasma renin activity $(-30 \%)$ which did reach significance. This may be because the number of sampling points (only two per study phase) was limited.

\section{Inhibition of neutral endopeptidase $3 \cdot 4 \cdot 24 \cdot 11$ in hypertension}

Single doses or limited doses of neutral endopeptidase inhibitors have produced an increase in plasma ANF and BNP together with natriuresis, increases in plasma and urine cGMP, and suppression of the RAAS. These doses had little effect on blood pressure. ${ }^{47}$ In contrast, chronic dosing with neutral endopeptidase inhibitors produces transient natriuresis, sustained elevation of cGMP, and a significant fall in arterial pressure in association with a delayed activation of the RAAS. 476768

\section{Heart failure}

Plasma natriuretic peptide levels are increased in heart failure in proportion to the severity of cardiac dysfunction. ${ }^{69}$ Positive correlations exist between circulating ANF and BNP levels and cardiac filling pressures, while natriuretic peptide concentrations are inversely related to indices of left ventricular function. In cardiac failure, the normal inverse relation between plasma natriuretic peptide concentrations and RAAS activity is replaced with a positive correlation, ${ }^{70}$ presumably reflecting simultaneous stimulation of both natriuretic peptide (secondary to cardiac chamber distension) and renin release (in response to decreased renal perfusion). The latter effect probably overcomes the inhibitory action of raised circulating natriuretic peptide on renin release.

In the absence of a specific antagonist to natriuretic peptides, we cannot conclusively define their place in the pathophysiology of heart failure in man. Nevertheless, data are available from elegant animal experiments. Lee et $a l^{71}$ examined two canine models of reduced cardiac output. Ligation of the thoracic inferior vena cava caused reductions in cardiac output, reduced systemic arterial pressure, increased peripheral vascular resistance, and decreased renal blood flow and activation of the RAAS. However, in contrast to the pacing induced model of heart failure in the dog, ventricular filling pressures are not raised and consequently plasma natriuretic peptides are not increased. In the inferior vena cava ligation model, sodium excretion is curtailed and RAAS activity is enhanced when compared with the pacing model. When ANF is given in the inferior vena cava ligation experiments to produce matching levels of plasma ANF to those observed in the paced model, sodium retention is ameliorated in association with suppression of the RAAS. In canine pacing induced heart failure, HS142 reduced plasma and urinary cGMP in a dose dependent fash- 
ion and inhibited natriuresis. ${ }^{72}$ Plasma renin activity and plasma aldosterone levels increased rapidly to double the control values. Endogenous natriuretic peptides attenuate activation of the RAAS and sodium retention in evolving heart failure.

In human heart failure, ANF consistently induces falls in cardiac preload and afterload, with transient increases in cardiac output and little change in heart rate. ${ }^{69}$ The inhibitory effects of ANF on the RAAS are attenuated in heart failure. However, the absence of change in plasma levels of renin, angiotensin II, and aldosterone, despite haemodynamic effects, presumably indicates some persisting inhibitory effect of ANF on the RAAS. ${ }^{69}$

In the only full report available ${ }^{73}$ on human heart failure (New York Heart Association classes II-IV), BNP given at a high dose (33 $\mathrm{pmol} / \mathrm{kg} / \mathrm{min}$ ) reduced left ventricular filling pressure and systemic vascular resistance while increasing cardiac output. In this study, BNP had no effect on heart rate or arterial pressure. Plasma aldosterone was suppressed while plasma renin activity was unchanged. In striking contrast to the attenuated natriuretic response to ANF usually observed in heart failure, these researchers reported an enhanced natriuretic response to BNP in comparison to that observed in normal controls. These findings require confirmation.

Endopeptidase inhibition in single and chronic dose studies has shown a beneficial effect in human heart failure, with reduction in left ventricular pressures and systemic arterial pressure and preservation of cardiac output in association with inhibition of renin activity. ${ }^{74-76}$

\section{Combined inhibition of ACE and neutral endopeptidase}

ACE inhibitors are an established treatment in hypertension and heart failure. ACE inhibition has the greatest haemodynamic effect when baseline activity of the RAAS is increased. As yet, neutral endopeptidase inhibition has no defined therapeutic application, although preliminary data suggest beneficial effects in hypertension and heart failure. However, efficacy may be curtailed by secondary activation of the RAAS. Hence combining these two modes of enzyme inhibition may augment the beneficial effects of either approach alone. Pham et $a l^{77}$ reported that in three rat models of hypertension neutral endopeptidase inhibition consistently enhanced natriuresis and levels of cGMP, ANF, and bradykinin. Blood pressure fell only in DOC-Na rats and was not altered in either SHR or renovascular hypertensive (two kidney, one clip) rats. ACE inhibition alone reduced blood pressure effectively in both SHR and renovascular animals, but not in the DOC-Na model. The two inhibitors combined augmented the diuresis and natriuresis observed in DOC-Na and SHR models and the fall in blood pressure in the SHR. Glucoprilat and alatrioprilat (which have combined enzyme inhibitory activity) given in low dose to rodents prevented hypertension secondary to infused angiotensin I and enhanced

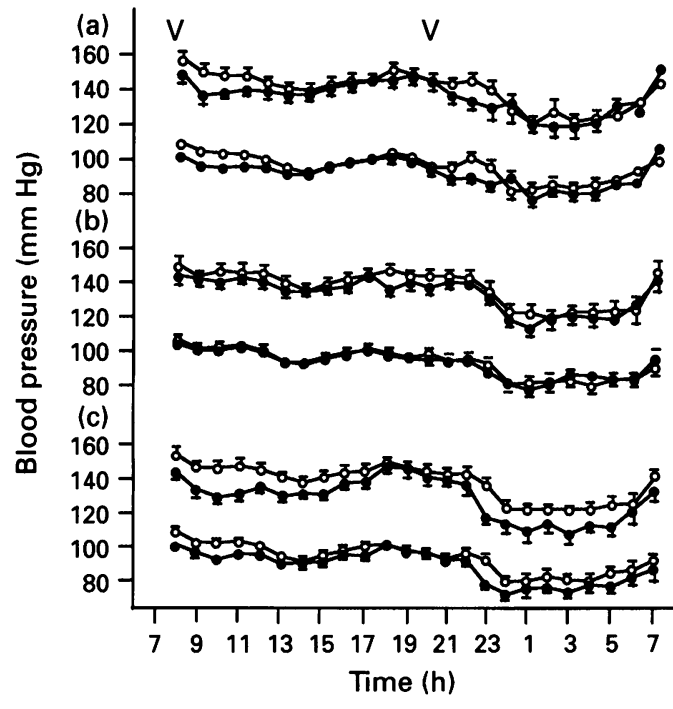

Figure 4 Serial integrated 1 h values of systolic and diastolic blood pressures obtained by ambulatory blood pressure recording on $(N)$ placebo or (O) active treatment. In (a) the effect of $25 \mathrm{mg}$ of captopril twice per day is compared with placebo; in (b) the effects of $100 \mathrm{mg}$ of sinorphan twice per day are compared with placebo; and in (c) the combined treatment and the mean of the two placebo phases are compared. Arrows indicate dose times. placebo phases are compared. Arrows indicate dose
Values are expressed as means, error bars = SEM. Reproduced with permission from Favrat et al. ${ }^{99}$

the natriuretic response to volume expansion. ${ }^{78}$ Taken together, these animal data suggest that the combination of ACE and neutral endopeptidase inhibition produces complementary biological effects, resulting in effective antihypertensive action across a range of forms of hypertension. The only available report in human hypertension showed that the combination of an neutral endopeptidase inhibitor (sinorphan) with an ACE inhibitor (captopril) resulted in significant falls in arterial pressure (fig 4), whereas (at the doses employed) neither agent given alone produced a clinically important antihypertensive effect. ${ }^{79}$

In heart failure, currently published data concerning combined ACE and neutral endopeptidase inhibition are confined entirely to animal experiments. Co-administration of captopril and an neutral endopeptidase inhibitor (SQ 28603) in canine pacing induced heart failure lowered arterial pressure and systemic and renal vascular resistance, while enhancing cardiac output and renal blood flow. ${ }^{80}$ This combination therapy warrants further trials in human hypertension and heart failure.

\section{Conclusion}

An intricate web of incompletely understood interactions has been found between the natriuretic peptides and the RAAS in health and disease. These interactions influence cardiovascular structure and function and pressure/volume homeostasis, and may be manipulated to cause a beneficial effect in hypertension and heart failure.

Original work from the author's group was supported by the National Heart Foundation and the Health Research Council of New Zealand. Expert secretarial assistance was provided by Barbara Griffin. 
1 de Bold AJ, Borenstein HB, Veress AT, Sonnenberg H. A rapid and potent natriuretic response to intravenous injection of atrial

2 Oikawa S, Imai $M$, Ueno A, Tanaka S, Noguchi $T$ Nakazato $\mathrm{H}$, et al. Cloning and sequence analysis of cDNA encoding a precursor for human atrial natriuretic polypeptide. Nature 1984;309:724-6.

polypeptide. Nature 1984;309:724-6.
3 Sudoh T, Kangawa K, Minamino N, Matsuo H. A new natriuretic peptide in porcine brain. Nature 1988;332: 78-81.

4 Sudoh T, Minamino N, Kangawa K, Matsuo H. C-type natriuretic peptide (CNP): a new member of natriuretic natriuretic peptide (CNP): a new member of natriuretic
peptide family identified in porcine brain. Biochem peptide family identified in porcine

5 Maack T, Suzuki M, Almeida FA, Nussenzveig D, Scarborough RM, McEnroe GA, et al. Physiological rol of silent receptors of atrial natriuretic factor. Science 1987;238:675-8.

6 Koller KJ, Lowe DG, Bennett GL, Minamino N, Kangawa $\mathrm{K}$, Matsuo $\mathrm{H}$, et al. Selective activation of the $\mathrm{B}$ natriuretic peptide receptor by C-type natriuretic peptide (CNP). Science 1991;252:120-3.

7 Kenny AJ, Bourne A, Ingram J. Hydrolysis of human and pig brain natriuretic peptides, urodilatin, C-type natriuretic peptide and some C-receptor ligand

8 Yandle TG. Biochemistry of natriuretic peptides. 7 Interm Med 1994;235:561-76.

9 Espiner EA. Physiology of natriuretic peptides. $f$ Intern Med 1994;235:527-41.

10 Sagnella GA, Markandu ND, Shore AC, MacGregor GA Effects of changes in dietary sodium intake and saline infusion on immunoreactive atrial natriuretic peptide in human plasma. Lancet 1985; ii:1208-11.

11 Anderson JV, Millar ND, O'Hare JP, Mackenzie JC Corrall RJ, Bloom SR. Atrial natriuretic peptide: physiological release associated with natriuresis during water logical release associated with natriuresis durit
immersion in man. Clin Sci 1986;71:319-22.

12 Richards AM, Nicholls MG, Ikram H, Webster MW, Yandle TG, Espiner EA. Renal, haemodynamic, and Yandle TG, Espiner EA. Renal, haemodynamic, and tide in healthy volunteers. Lancet 1985 ;i:545-9.

13 Weidmann P, Gnädinger MP, Ziswiler HR, Shaw S Bachmann C, Rascher W, et al. Cardiovascular, endocrine and renal effects of atrial natriuretic peptide in

14 essential hypertension. F Hypertens Suppl 1986;4:S71-83. MG, Espiner EA, Ikram $\mathrm{H}$, et al. Atrial natriuretic hormone has biological effects in man at physiological plasma concentrations. $\mathcal{F}$ Clin Endocrinol Metab 1988;67: 1134-9.

15 Lang CC, Struthers AD. Effects of atrial natriuretic factor on the renin-angiotensin-aldosterone system. In: Struthers $\mathrm{AD}$, ed. Atrial natriuretic factor. Oxford: Blackwell Scientific Publications, 1990:115-40.

16 de Zeeuw D, Janssen WM, de Jong PE. Atrial natriuretic factor: its (patho)physiological significance in humans. Kidney Int 1992;41:1115-33.

17 Holmes SJ, Espiner EA, Richards AM, Yandle TG, Frampton C. Renal, endocrine, and hemodynamic Frampton C. Renal, endocrine, and hemodynamic effects of human brain natriuretic peptide

18 Cargill RI, Struthers AD, Lipworth BJ. Comparative effects of atrial natriuretic peptide and brain natriuretic peptide on the aldosterone and pressor responses to angiotensin II in man. Clin Sci 1995;88:81-6.

19 Hunt PJ, Richards AM, Espiner EA, Nicholls MG, Yandle TG. Bioactivity and metabolism of C-type natriuretic peptide in normal man. $\mathcal{F}$ Clin Endocrinol Metab 1994;78 1428-35

20 Cuneo RC, Espiner EA, Nicholls MG, Yandle TG, Livesey $\mathrm{JH}$. Effect of physiological levels of atrial natriuretic peptide on hormone secretion: inhibition of angiotensininduced aldosterone secretion and renin release in n

mal man. 7 Clin Endocrinol Metab 1987;65:765-72.
Harris PJ, Thomas D, Morgan TO. Atrial natriuretic peptid inhibits angiotensin-stimulated proximal tubular sodium and water reabsorption. Nature 1987;326:697-8.

22 Rabelink TJ, Koomans HA, van de Stolpe A, Bijlsma JA, Dorhout Mees EJ. Effects of atrial natriuretic peptide on distal tubule

23 Garcia NH, Garvin JL. ANF and angiotensin II interact via kinases in the proximal straight tubule. Am f Physio 1995;268:F730-5.

24 McMurray J, Struthers AD. Renal effects of angiotensin II, atrial natriuretic peptide and their interaction in man. II, atrial natriuretic peptide and

25 Hollenberg NK, Chenitz WR, Adams DF, Williams GH. Reciprocal influence of salt intake on adrenal glomeruReciprocal influence of salt intake on adrenal glomerumal man. $\mathcal{~}$ Clin Invest 1974;54:34-42.

26 Richards AM, Tree M, Tonolo G, Montorsi P, Polonia J Morton JJ, et al. Atrial natriuretic factor and changes in Morton J, et al. Atrial natriuretic factor and changes in the aldosterone response to angiotensin II in sodiu

27 Tuchelt H, Eschenhagen G, Bähr V, Schwietzer G, Thiede $\mathrm{HM}$, Oelkers $\mathrm{W}$. Role of atrial natriuretic factor in changes in the responsiveness of aldosterone to angiotensin II secondary to sodium loading and depletion in man. Clin Sci 1990;79:57-65.

28 Clinkingbeard C, Sessions C, Shenker Y. The physiological role of atrial natriuretic hormone in the regulation of aldosterone and salt and water metabolism. $f$ Clin Endocrinol Metab 1990;70:582-9.

29 Northridge DB, McMurray J. The cardiovascular effects of atrial natriuretic factor. In: Struthers $\mathrm{AD}$, ed. Atrial natriuretic factor. Oxford: Blackwell Scientific Publications, 1990:57-87.

30 Marin-Grez M, Fleming JT, Steinhausen M. Atrial natriuretic peptide causes pre-glomerular vasodilatation and post-glomerular vasoconstriction in rat kidney. Nature post-glomerular

31 Berk BC, Vekshtein V, Gordon HM, Tsuda T. Angiotensin II-stimulated protein synthesis in cultured vascular II-stimulated protein synthesis in cultured vas

32 Abell TJ, Richards AM, Ikram H, Espiner EA, Yandle T Atrial natriuretic factor inhibits proliferation of vascular Atrial natriuretic factor inhibits proliferation of vascular smooth muscle cells stimulated by platelet-derived growth fact

33 Itoh H, Pratt RE, Dzau VJ. Interaction of atrial natriuretic polypeptide and angiotensin II on protooncogene expression and vascular cell growth. Biochem Biophys Res Commun 1991;176:1601-9.

34 Cao L, Gardner DG. Natriuretic peptides inhibit DNA synthesis in cardiac fibroblasts. Hypertension 1995;25 227-34.

35 Gavras H, Kremer D, Brown JJ, Gray B, Lever AF, MacAdam RF, et al. Angiotensin- and norepinephrineinduced myocardial lesions: experimental and clinical studies in rabbits and man. Am Heart $\mathcal{F} 1975 ; 89: 321-32$.

36 Crozier I, Richards AM, Foy SG, Ikram H. Electrophysiological effects of atrial natriuretic peptide on the cardiac conduction system

37 Linz W, Schölkens BA, Albus U, Petry P, Breipohl G Knolle J. Atrial natriuretic factor protects the isolated working ischaemic rat heart against the action of angiotensin II. $\mathcal{F}$ Hypertens Suppl 1988;6:S339-41.

38 tensin $\mathrm{H}$, Nakao K, Yamada T, Morii N, Shiono S Itoh H, Nakao K, Yamada T, Morii N, Shiono S, of secretion of atrial natriuretic factor from the heart. of secretion of atrial natriuretic

39 Charles CJ, Richards AM, Espiner EA. Central C-type natriuretic peptide but not atrial natriuretic factor lowers blood pressure and adrenocortical secretion in normal conscious sheep. Endocrinology 1992;131:1721-6.

40 Katsube N, Schwartz D, Needleman P. Release of atriopeptin in the rat by vasoconstrictors or water immersion correlates with changes in right atrial pressure. Biochem Biophys Res Commun 1985;133:937-44.

41 Shenker Y, Bates ER, Egan BH, Hammoud J, Grekin RI Effect of vasopressors on atrial natriuretic factor and hemodynamic function in humans. Hypertension 1988; 12:20-5.

42 Volpe $M$, Atlas SA, Sosa RE, Marion DE, Mueller FB, Sealey JE, et al. Angiotensin II-induced atrial natriuretic factor release in dogs is not rela

43 Tang J, Webber RJ, Chang D, Chang JK, Kiang J, Wei ET. Depressor and natriuretic activities of several atrial pep-
tides. Regul Pept 1984;9:53-9.

44 Richards AM, Rao G, Espiner EA, Yandle T. Interaction of angiotensin converting enzyme inhibition and atrial natriangiotensin converting enzyme inhibition

45 Kawaguchi H, Sawa H, Yasuda H. Effect of atrial natriuretic factor on angiotensin converting enzyme. $\mathcal{F}$ Hypertens 1990;8:749-53.

46 Wegner M, Stasch JP, Hirth-Dietrich C, Dressel J, Voges $\mathrm{KP}$, Kazda S. Interaction of a neutral endopeptidase inhibitor with an ANP-C receptor ligand in anesthetized dogs. Clin Exp Hypertens 1995;17:861-76.

47 Connell JMC, Jardine A. Neutral endopeptidase and atrial natriuretic factor. In: Struthers AD, ed. Atrial natriuretic factor. Oxford: Blackwell Scientific Publications, 1990 181-94

48 Richards M, Espiner E, Frampton C, Ikram H, Yandle T, Sopwith M, et al. Inhibition of endopeptidase EC $24 \cdot 11$ in humans. Renal and endocrine effects. Hypertension 1990;16:269-76.

49 Richards AM, Wittert G, Espiner EA, Yandle TG, Frampton C, Ikram H. Prolonged inhibition of endopeptidase 24.11 in normal man: renal, endocrine and haemodynamic effects. F Hypertens 1991;9:955-62.

50 Richards AM, Wittert GA, Espiner EA, Yandle TG, Ikram $H$, Frampton C. Effect of inhibition of endopeptidase 24.11 on responses to angiotensin II in human volunteers. Circ Res 1992;71:1501-7.

51 Morishita Y, Sano T, Ando K, Saitoh Y, Kase H, Yamada $\mathrm{K}$, et al. Microbial polysaccharide, HS-142-1, competitively and selectively inhibits ANP binding to its guanylyl tively and selectively inhibits ANP binding to its guanylyl
cyclase-containing receptor. Biochem Biophys Res cyclase-containing receptor.

52 Stasch JP, Hirth C, Kazda S, Neuser D. The reduction of renin and aldosterone as a response to acute of renin and aldosterone as a response to acute directed against atrial natriuretic peptides. Life Sci 1988; 4irected agair

53 Rudd MA, Plavin S, Hirsch AT, Ingelfinger JR, Dzau VJ. Atrial natriuretic factor-specific antibody as a tool for physiological studies. Evidence for role of atrial natriuretic factor in aldosterone and renal electrolyte regulation. Circ Res 1989;65:1324-9.

54 Sano T, Morishita Y, Matsuda Y, Yamada K. Pharmacological profile of HS-142-1, a novel nonpep-
tide atrial natriuretic peptide antagonist of microbial ori- 
gin. I. Selective inhibition of the actions of natriuretic peptides in anesthetized rats. $f$ Pharmacol Exp Ther 1992; 260:825-31.

55 Richards AM. The natriuretic peptides and hypertension. $f$ Intern Med 1994;235:543-60

56 Luparini RL, Ferri C, Santucci A, Balsano F. Atrial natriuretic peptide in non-modulating essential hypertension. Hypertension 1993;21:803-9.

57 Williams GH, Moore TJ, Hollenberg NK. Renal abnormalities in nonmodulating essential hypertension. $\mathrm{Am} f$ Kidney Dis 1987;10 suppl 1:39-44.

58 Matsubara H, Umeda Y, Yamane Y, Nishikawa M, Taniguchi T, Inada $M$. Role of atrial natriuretic polypeptides for exaggerated natriuresis in essential hypertension.

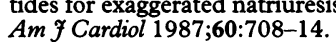

59 Cheung BM, Brown MJ. Plasma brain natriuretic peptide and C-type natriuretic peptide in essential hypertension. and C-type natriuretic peptide

60 Furuya M, Yoshida M, Hayashi Y, Ohnuma N, Minamino $\mathrm{N}$, Kangawa $\mathrm{K}$, et al. C-type natriuretic peptide is a growth inhibitor of rat vascular smooth muscle cells. Biochem Biophys Res Commun 1991;177:927-31.

61 Tonolo G, Richards AM, Manunta P, Troffa C, Pazzola A, Madeddu $\mathrm{P}$, et al. Low-dose infusion of atrial natriuretic factor in mild essential hypertension. Circulation 1989;80:893-902.

62 Richards AM, Espiner EA, Ikram H, Yandle TG. Atrial natriuretic factor in hypertension: bioactivity at normal plasma levels. Hypertension 1989;14:261-8.

63 Ferri C, Baldoncini R, Bellini C, Di Francesco L, Luparini $R L$, Cacciafesta $M$, et al. Hormonal and renal responses to atrial natriuretic peptide infusion in low-renin hypertension. Am $₹$ Nephrol 1995;15:222-9.

64 Hirata Y, Ishii M, Sugimoto T, Matsuoka $H$, Fukui $K$, Sugimoto $\mathrm{T}$, et al. Hormonal and renal effects of atrial natriuretic factor in humans. Hypertension 1989;13: 640-6.

65 Richards AM, Crozier IG, Holmes SJ, Espiner EA, Yandle TG, Frampton C. Brain natriuretic peptide: natriuretic and endocrine effects in essential hypertension. $f$ Hypertens 1993;11:163-70.

66 Lazzeri C, Franchi F, Porciani C, Fronzaroli C, Raggi VC, De Feo ML, et al. Systemic hemodynamics and renal function during brain natriuretic peptide infusion in function during brain natriuretic peptide infusion in patients with essen
$1995 ; 8: 799-807$.

67 Richards AM, Wittert GA, Crozier IG, Espiner EA, Yandle TG, Ikram H, et al. Chronic inhibition of endopeptidase 24.11 in essential hypertension: evidence for enhanced atrial natriuretic peptide and angiotensin II. f Hypertens 1993;11:407-16.

68 Richards AM, Crozier IG, Kosoglou T, Rallings M,
Espiner EA, Nicholls MG, et al. Endopeptidase 24.11 inhibition by $\mathrm{SCH} 42495$ in essential hypertension. Hypertension 1993;22:119-26.

69 Nicholls MG. The natriuretic peptides in heart failure. $f$ Intern Med 1994;235:515-26.

70 Richards AM, Tonolo G, Tree M, Robertson JI, Montorsi $\mathrm{P}$, Leckie BJ, et al. Atrial natriuretic peptides and renin release. Am $\mathcal{F}$ Med 1988;84:112-8.

71 Lee ME, Miller WL, Edwards BS, Burnett JC Jr. Role of endogenous atrial natriuretic factor in acute congestive heart failure. $\mathcal{F}$ Clin Invest 1989;84:1962-6.

72 Wada A, Tsutamoto T, Matsuda Y, Kinoshita M. Cardiorenal and neurohumoral effects of endogenous atrial natriuretic peptide in dogs with severe congestive heart failure using a specific antagonist for guanylate cyclasecoupled receptors. Circulation 1994;89:2232-40.

73 Yoshimura M, Yasue H, Morita E, Sakaino N, Jougasaki M, Kurose M, et al. Hemodynamic, renal, and hormonal responses to brain natriuretic peptide infusion in patients responses to brain natriuretic peptide infusion in patients
with congestive heart failure. Circulation 1991;84:1581-8.

74 Northridge DB, Jardine AG. Alabaster CT, Barclay PL, Connell JM, Dargie HJ, et al. Effects of UK 69, 578: a novel atriopeptidase inhibitor. Lancet 1989;ii:591-3.

75 Elsner D, Müntze A, Kromer EP, Riegger GA. Effectiveness of endopeptidase inhibition (candoxatril) in congestive heart failure. Am $\mathcal{F}$ Cardiol 1992;70:494-8.

76 Münzel T, Kurz S, Holtz J, Busse R, Steinhauer H, Just H, et al. Neurohormonal inhibition and hemodynamic unloading during prolonged inhibition of ANF degradation in patients with severe chronic heart failure. Circulation 1992;86:1089-98.

77 Pham I, Gonzalez W, el Amrani AI, Fournié-Zaluski MC, Philippe M, Laboulandine I, et al. Effects of converting enzyme inhibitor and neutral endopeptidase inhibitor on blood pressure and renal function in experimental hypertension. F Pharmacol Exp Ther 1993;265:1339-47.

78 Gros C, Nol N, Souque A, Schwartz JC, Danvy D, Plaquevent JC, et al. Mixed inhibitors of angiotensinconverting enzyme (EC $3 \cdot 4 \cdot 15 \cdot 1)$ and enkephalinase (EC $3 \cdot 4 \cdot 24 \cdot 11$ ): rational design, properties, and potential car$3 \cdot 4 \cdot 24 \cdot 11)$ : rational design, properties, and potential car-
diovascular applications of glycopril and alatriopril. Proc diovascular applications of glycopril
Natl Acad Sci USA 1991;88:4210-4.

79 Favrat B, Burnier M, Nussberger J, Lecomte JM, Brouard $\mathrm{R}$, Waeber $\mathrm{B}$, et al. Neutral endopeptidase versus angiotensin converting enzyme inhibition in essential hypertensin converting enzyme inhibition in

80 Seymour AA, Asaad MM, Lanoce VM, Langenbacher KM, Fennell SA, Rogers WL. Systemic hemodynamics, renal function and hormonal levels during inhibition of renal function and hormonal levels during inhibition of neutral endopeptidase $3 \cdot 4 \cdot 24 \cdot 11$ and angiotensin-con-
verting enzyme in conscious dogs with pacing-induced verting enzyme in conscious dogs with pacing-induced
heart failure. $\mathcal{F}$ Pharmacol Exp Ther 1993;266:872-83. 